[Vol. 102

\title{
NOTE
}

\section{THE ANTHRACITE COAL PRODUCTION CONTROL PLAN}

On January 29, 1940, by the agreement of Governor James of Pennsylvania, the United Mine Workers of America and industry representatives, the Anthracite Coal Production Control Plan came into effect; ${ }^{1}$ on July 7, 1941, the Plan was given legislative approval by way of an amendment to the Commerce Law of Pennsylvania. ${ }^{2}$ This plan is still in operation. By setting production quotas for those anthracite companies which have chosen to cooperate, the Plan succeeded in improving the financial status of the industry after a decade of economic chaos resulting from competition from other fuels and cutthroat price competition within the anthracite industry itself."

That it has played a part in preserving the industry may be a strong recommendation for the Plan. However, there is some doubt as to the economic and legal soundness of the adopted approach. The Plan has resulted in a limitation of anthracite coal production since 1940, with the exception of the years 1942 to 1948 when wartime conditions called for unlimited production. The decline in production has been accompanied by declining sales and rising prices. In addition, the employment of production controls in an industry engaged in interstate commerce raises two substantial legal problems: is this action a combination in restraint of trade or an attempt to create a monopoly, violative of the Sherman Antitrust Act; ${ }^{4}$ or, does the Plan constitute action by the Commonwealth of Pennsylvania which conflicts with the federal commerce power and is prohibited by the commerce clause of the Constitution? In order to evaluate the Plan in the light of these problems, it is necessary to make a case study of a declining industry, a detailed examination of the operation of the attempted solution, and an evaluation of possible alternative solutions.

1. Pa. Dep't of Commerce, Production Control Plan for the Anthractie INDUSTRY (Jan. 29, 1940) (Hereinafter cited as Anthracite Production Control Plan).

2. Pa. Stat. Ann. tit. 71, \$1709-3 (Purdon 1942).

3. Since almost $95 \%$ of known deposits of anthracite in the United States are located in Pennsylvania, it was to that State that the industry turned for aid. RaIlroad Committee, Anthracite Coal 29 (1945). See Wilcox, Competition and MONOPOLY 179 (TNEC Monograph 21, 1941).

4. 15 U.S.C. $\$ 1,2$ (1946). 


\section{TABLE I}

\section{Production of Anthractie Coal in Tons $\dagger$}

\begin{tabular}{|c|c|c|c|c|}
\hline 1890 & $46,468,641$ & 1933 & $49,541,344$ & \\
\hline 1895 & $57,997,337$ & 1934 & $57,168,291$ & \\
\hline 1900 & $57,367,915$ & 1935 & $52,158,783$ & \\
\hline 1905 & $77,659,850$ & 1936 & $54,579,535$ & \\
\hline 1910 & $84,485,236$ & 1937 & $51,856,433$ & \\
\hline 1915 & $88,995,061$ & 1938 & $46,099,027$ & \\
\hline 1917 & $99,611,811$ & 1939 & $51,487,377$ & \\
\hline 1920 & $89,598,249$ & 1940 & $51,484,640$ & \\
\hline 1921 & $90,473,451$ & 1941 & $56,368,267$ & \\
\hline 1922 & $54,683,022$ & 1942 & $60,327,729$ & \\
\hline 1923 & $93,339,009$ & 1943 & $60,643,620$ & \\
\hline 1924 & $87,926,862$ & 1944 & $63,701,363$ & \\
\hline 1925 & $61,817,149$ & 1945 & $54,933,909$ & \\
\hline 1926 & $84,437,452$ & 1946 & $60,506,873$ & \\
\hline 1927 & $80,095,564$ & 1947 & $57,190,009$ & \\
\hline 1928 & $75,348,069$ & 1948 & $57,139,948$ & \\
\hline 1929 & $73,828,195$ & 1949 & $42,701,724$ & excludes Sullivan \\
\hline 1930 & $69,384,837$ & 1950 & $44,076,703$ & County which usu- \\
\hline 1931 & $59,645,652$ & 1951 & $42,079,667$ & ally produces less \\
\hline 1932 & $49,855,221$ & $1952 *$ & $39,797,000$ & $\begin{array}{l}\text { than } 1,000,000 \\
\text { tons. }\end{array}$ \\
\hline
\end{tabular}

$\dagger$ from Bureau of Mines, Minerals Yearbook 350, 351 (1950) and Anthracite Institute, Mannal of Statistical Information Table 1 (1953).

* preliminary.

\section{History of Attempts at Anthracite Stabilization}

Table I illustrates that although from 1830 to 1917 anthracite production generally increased in the typical pattern of American industry, since 1917 production has been in a period of decline. This situation stems mainly from competition from other fuels, but partly from high prices resulting from successive monopolistic practices within the industry. The history of the industry shows a pattern of events which has led operators to attempt various methods of controlling intra-industry competition.

An early use of monopolistic devices occurred when eight railroads controlled the eight major mining companies; this railroad-coal mining combination was advantageous since transportation of coal from mine to tidewater is an important and costly factor in the coal industry. ${ }^{5}$ In 1895

5. Wilcox, Conpetition and Monopoly 179-80 (TNEC Monograph 21, 1941). 
these anthracite "line companies" owned 95\% of the available holdings. Pooling agreements, price leadership and market sharing were the chief methods of avoiding competition. ${ }^{6}$ Six of the line companies, which then produced about $75 \%$ of the annual output, were convicted in 1912 of restraint of trade by preventing the construction of a new railroad to service the independent companies and by signing identical contracts for the purchase of all the independent production in order to prevent its affecting the price of coal. ${ }^{7}$

During World War I demand far exceeded supply. Production was increased over 10 million tons from 1916 to 1917. In addition, an allotment plan was devised which actually cut shipments to the central and western states. ${ }^{8}$ Later, the postwar decrease in demand resulted in a capacity to produce more than the market required. The slighted markets in the central and western states were never fully regained from the inroads of bituminous coal; simultaneously, anthracite was being replaced as a railroad fuel. ${ }^{9}$

In 1920 the Supreme Court compelled the divorce of the Philadelphia \& Reading Coal and Iron Company, the Philadelphia and Reading Railway Company, and the Central Railroad Company of New Jersey; ${ }^{10}$ the three had been owned by the Reading Company, a holding company which had been the price leader in the industry since 1902.11 The Court commented that ". . . this dominating power was not obtained by normal expansion to meet the demands of a business growing as a result of superior and enterprising management, but by deliberate, calculated purchase for control." 12 Shortly thereafter the other line companies with one exception were voluntarily divorced from the railroad companies.

In the winters of 1922-3 and 1925-6 severe strikes cut all shipments and again the western states suffered most. ${ }^{13}$ It was at this time that petroleum consumption increased and natural gas first made real progress as a heating fuel, both at the expense of anthracite coal. ${ }^{14}$ Table II shows that these inroads continued during the thirties and forties. Not only did the other fuels increase their markets at the expense of possible anthracite expansion, but they also made inroads on the existing anthracite market, causing a net decline in anthracite production.

6. Ibid.

7. United States v. Reading Co., 226 U.S. 324 (1912).

8. Mead, Analysis of the Decline of the Anthracite Industry 37-40 (1935).

\section{Ibid.}

10. United States v. Reading Co., 253 U.S. 26 (1920). The convictions were under the Hepburn Act, 34 STAT. 584 (1906), 49 U.S.C. \$1(8) (1946) and sections 1 and 2 of the Sherman Act, 15 U.S.C. $\$ \$ 1,2$ (1946).

11. Burns, Decline of Comperitron 118 (1936).

12. United States v. Reading Co., 253 U.S. 26, 57 (1920).

13. MEAD, op. cit. supra note 8 , at 40-1.

14. Id. at 56 et seq. 
TABLE II

Annual Supply of Energy from Mineral Fuels and Water Power in the United States, 1900-1950, in Trillions of B.T.U.

$\begin{array}{rcrrrrr} & \text { Natural } & \text { Bitum. } & & \text { Pa. } & & \\ \text { Year } & \text { Gas } & \text { Coal } & \text { Petroleum } & \text { Anth. } & \text { Water } & \text { Total } \\ 1900 & 254 & 5563 & 369 & 1457 & 250 & 7893 \\ 1910 & 547 & 10928 & 1218 & 2146 & 539 & 15378 \\ 1920 & 858 & 14899 & 3185 & 2276 & 738 & 21956 \\ 1930 & 2089 & 12249 & 5568 & 1762 & 752 & 22420 \\ 1935 & 2060 & 9756 & 5967 & 1325 & 806 & 19914 \\ 1940 & 2860 & 12072 & 8096 & 1308 & 880 & 25216 \\ 1945 & 4213 & 15134 & 10368 & 1395 & 1442 & 32552 \\ 1950 & 6583 & 13414 & 12440 & 1128 & 1572 & 35137\end{array}$

from American Gas Association, Gas Facts 28 (1950).

Anthracite market losses have been mostly in the field of domestic heating, which in 1951 consumed $56.6 \%$ of anthracite production. ${ }^{15}$ In domestic use the greater convenience of gas and oil is their chief selling characteristic since their prices are generally higher than anthracite. ${ }^{16}$

The production decline in the 1930's was, of course, aggravated by the general depression. Nevertheless, from 1929 to 1933 anthracite did not decrease in price as much as did the index of all wholesale prices. ${ }^{17}$ About 1936, however, a period of cutthroat competition began. ${ }^{18}$ As the market

15. For example, from 1942 to 1952 the production of sizes for domestic use declined 16 million tons while steam sizes for industrial use declined only 4 million tons. Anthracite Institute, Manual of Statistical Information, Table 7 (1953). Within the principal anthracite markets of New England and the Middle Atlantic States the consumption of anthracite from 1947 to 1950 decreased from 44 to 33 million tons while the consumption of oil in the same region in coal equivalents (4 barrels of oil to 1 ton of coal) increased from 44 to 53 million tons. Minerals YEARBOOK, 1950, 375 (1953).

16. Comparison of prices is an unsatisfactory procedure at best, but some indications may be given. Granting coal its most efficient conversion value of 13,500 BTU per pound, considering gas at 700 BTU per cubic foot (Philadelphia Gas Works, 1952-53), and considering oil at 138,500 BTU per gallon, coal costs $\$ .88$, oil $\$ .93$, and gas $\$ 1.33$ per one million BTU at prices in Philadelphia during the winter of 1952-53. The price of coal is on chestnut size, but the conversion equivalent is not adjusted for the inefficiencies of the conventional hand-fired furnace in which that size coal is used. The price for gas may be substantially reduced in a home which uses a great quantity in all of its appliances but it would not reach $\$ .90$ per million BTU.

It has been said that the "only weapon which anthracite can use to answer the question af convenience is the promotion of the sale of the domestic stoker." MEEAD, Analysis of the Decine of the ANTHRacite Industry 117 (1935). However, stoker sales are generally decreasing. 12 FUEL OIL AND OIL HEAT 60 (Jan. 1953).

17. Burns, Decline of Competition 189 (1936); Wilcox, Competition and Monopoly 181 (TNEC Monograph 21, 1941); MEAD, ANalysis of tHe DeCLINE of THE ANTHRACITE INDUSTRY 87 (1935).

18. See Lehigh Coal and Navigation Co., 1936 Annual Report 21, 1938 AnNual Report 23; Lemigh Valley Coal Co., 1937 Annual Report 1, 1939 AnNual Report 2; Glen Alden Coal Co., 1938 AnNual Report 4, 1939 ANNUal. Report 2; Philadelphia and Reading Coal and Iron Co., 1939 Annuad Report 10. 
diminished more and more the competition for that market among anthracite companies increased. The results were severe price slashing and great losses to the individual companies. The decrease in demand during the depression, the overcapacity from boom times and the increased price competition combined to affect adversely the income and working capital of the industry, as illustrated in Table III.

TABLE III

Net Incone and Working Capital of Companies Accounting for Approximately 90\% of Anthracite Production 1926-40, IN Militons

$\begin{array}{lccccc}\text { Year } & \text { Net Inc. } & \text { Wkng. Cap. } & \text { Year } & \text { Net Inc. } & \text { Wkng. Cap. } \\ 1926 & 33.8 & 111.1 & 1933 & -8.6 & 16.5 \\ 1927 & 13.8 & 99.8 & 1934 & -1.7 & 16.3 \\ 1928 & 15.1 & 89.5 & 1935 & -10.2 & 8.9 \\ 1929 & 15.2 & 69.9 & 1936 & -2.4 & -4.6 \\ 1930 & 13.4 & 44.2 & 1937 & -17.4 & -10.8 \\ 1931 & -8.6 & 33.0 & 1938 & -14.8 & -27.0 \\ 1932 & -10.5 & 22.7 & 1939 & -14.9 & -15.7 \\ & & & 1940 & -.5 & -10.6\end{array}$

from Hearing before Committee on Banking and Currency on Economic Power of Labor Organizations, 81st Cong., 1st Sess. 259 (1949).

An industry which had a net income of almost $\$ 14$ million and a working capital of almost $\$ 100$ million in 1927 , lost $\$ 17$ million and its current liabilities exceeded current assets by almost $\$ 11$ million in 1937. In the summers of $1938^{19}$ and $1939,{ }^{20}$ in the midst of price wars, costs of production exceeded selling prices for the whole industry. Not only were the companies hard hit but the entire coal region was crippled. Employment which had a peak of 156,000 in $1917^{21}$ dropped to 102,000 in $1936,96,000$ in 1938, and 91,000 in $1940 .{ }^{22}$ From 1936 to 1940 the average work week was a little more than $31 / 2$ days. $^{23}$

Conditions causing such havoc to operators and miners alike presented a problem which was approached in two ways: by cooperation among the various producing companies and by introduction of legislation in the Pennsylvania legislature. An Anthracite Coal Industry Commission was created by the Commonwealth of Pennsylvania and it reported in 1937 that a once rich industry had neglected to compete with other fuels, concentrating in-

19. Glen Alden Coal Co., 1938 Annual Report 4, 1939 Annual Report 2. (1941).

20. Lehigh Valley Coal Co., 1939 Annual Report 2; 24 Pa. Legis. J. 4497

21. Hard Times in Hard Coal Country, Business Week, Mar. 22, 1952, p. 108.

22. 53 MoNTHLy LaboR ReVIEW 618 (1941).

23. Ibid. 
stead on squeezing every penny from the consumer. The Commission recommended government regulation of some kind. ${ }^{24}$ The larger bituminous industry had been put under federal regulation, ${ }^{25}$ but the anthracite industry did not want government regulation. It failed to agree on a code of fair competition under the N.R.A. ${ }^{26}$ During an extraordinary session of the Pennsylvania legislature called in 1938, four bills ${ }^{27}$ were introduced providing for regulation of production, minimum and maximum prices, marketing, and for the acquisition of coal lands by the state so that it might mine and sell coal. These bills were attacked and successfully bottled up in committee by the industry. ${ }^{28}$

Meanwhile, in 1935, and again in 1938, the industry set up a price filing system whereby each company published its prices for the benefit of the rest of the companies, but both times the plan failed to aid the industry because the companies continually sold below published prices. ${ }^{29}$ By 1939 the larger companies desired production control to eliminate the oversupplies which caused destructive price cutting. With the cooperation of Governor James, a temporary production control plan was established on March 4, 1939,30 but it was abandoned when a bill to make it permanent and compulsory was defeated by a tie vote of 24-24 in the state Senate on May 27, 1939,31 despite the facts that it did not set maximum prices and that companies representing $80 \%$ of the production favored it. ${ }^{32}$ It was presented as an "effort to stabilize the industry and to help anthracite . . . in meeting its real problem of external competition." 33 Many independents were among those who opposed the measure on the grounds that it favored the line companies, that it was an attempt at monopoly and price fixing, that it did not aid the consumer and that anthracite was not different from any other depressed industry. Two line companies also opposed the bill on the basis that all voluntary methods of control had not been exhausted. ${ }^{\mathbf{3 4}}$

Private attempts to stabilize prices brought on a federal anti-trust prosecution against 28 corporations for fixing and agreeing to maintain prices from 1938 to 1942 . The defendants pleaded nolo contendere and escaped with minor fines, Judge Knox commenting, "Indeed if the detri-

24. Report of the Anthracite Coal Industry Commission, 21 PA. LEGrs. J. 7916-9 (1937).

25. 49 Stat. 991 (1935) (Guffey Coal Act); 50 Stat. 72 (1937) (Bituminous Coal Act of 1937); see Rostow, Bituminous Coal and the Public Interest, 50 Y L.J. 543 (1941); Hamilton, Coal and the Economy-A Demurrer, 50 id. at 595; Rostow, Joinder in Demurrer, 50 id. at 613.

26. Hearings before subcommittee on Interstate Commerce on $S$. 1417, 74th

Cong., 1st Sess. 574 (1935).

27. H. Bills 43-6, 22 PA. LEGIS. J. 148 (1938). (1938).

28. Glen Alden Coal. Co., 1938 Annual Report 2; 22 Pa. Legis. J. 316

29. Glen Alden Coal Co., 1938 Annual Report 1; Lehigh Coal and Navtgatron Co., 1936 AnNual Report 21. (1939).

30. Glen Alden Coal Co., 1939 Annuat Report 1-2; 23 Pa. Legis. J. 4836

31. H. Bill 1221, 23 PA. Legrs. J. 1326, 4842 (1939).

32. Id. at 1326,4831 .

33. Id. at 4831 .

34. Id. at $3503,4840,4841,4828,4833,4834,4830,4842$. 
ment that has come to the public were to be balanced against the advantages it has received, one might plausibly argue that the defendants, instead of being evil-minded malefactors, were animated by worthy motives, and accomplished good ends." 35

After another summer of severe competition in 1939 during which, according to the industry, production capacity was $50 \%$ greater than that required to meet market demand, ${ }^{36}$ the present Plan was originated. Industry representatives adopted some of the provisions of the 1939 bill and calculated for each cooperating company in the industry a percentage of the total anthracite output, based on the company's historical record of production. This series of percentages became Schedule A of the Plan. Reportedly, as much as $99 \%$ of the producing capacity of the industry agreed to the Plan at its inception. ${ }^{37}$ The Plan was then presented to the Committee of Twelve, an industry-union arbitration group. The United Mine Workers, represented by John L. Lewis and Philip Murray, duly signed because of an interest in a healthy industry and in order to secure better wages and working conditions; ${ }^{38}$ the operators, having originated the plan, of course signed. Governor James, who had agreed on condition that the union sign, approved the plan on January 23,1940, and it went into effect six days later. In 1941 it was felt necessary to obtain legislative approval. In reporting to the legislature what the Plan had accomplished so far, Representative Schwab said:

"This program, a voluntary one, has brought about a marked degree of stability within the industry. Producers have been able to meet current tax liabilities and to pay off overdue obligations. Employment has been stabilized and is showing a marked increase.

"All interested parties are wholeheartedly in accord with this voluntary program and they now wish to have the Legislature approve in a formal way what they have been doing informally since January of 1940." 39

Two years and a fait accompli had worked a great change in attitude. Not a voice was raised against the program as it passed the House 199-0 40 and the Senate $45-0 .{ }^{41}$ The sole opposition was a lonely telegram of protest. ${ }^{42}$

35. United States v. Glen Alden Coal Co., Criminal No. 113-391, S.D.N.Y. (pleas of nolo contendere entered May 2, 1944). 62 infra.

3625 PA. LEGIS. J. 4059 (1941). As to "demand" see text preceding note

37. 46 CoAL AgE 44 (Feb. 1941).

38. 25 PA. LEGIS. J. 4498 (1941).

39. Id. at 4059. Some of Mr. Schwab's assertions in 1941 can be checked against the record. The Anthracite Committee's report to the 1953 session of the legislature claims to have maintained "stability" in the face of severe conditions. The year after the Plan went into effect, 1940, three of the four line companies whose records are available had profits for the first time in several years. See text at note 72 et seq. infra.

40. Ibid.

41. Id. at 4498.

42. Id. at 4014 . 


\section{THE PLAN}

The Plan is a document separate from and temporally prior to the statute authorizing it $\mathbf{4 3}$ and consists of six subdivided articles subscribed to by operators and the United Mine Workers. In 1941 it was adopted under the statute and promulgated by the Department of Commerce as a Production Control Plan for the Anthracite Industry. It is administered

43. Pa. Stat. ANn. tit. 71, §1709-3 (Purdon Supp. 1952).

"Section 3. The Department of Commerce shall have the power, and its duty shall be:

“...

"(12) (a) To promulgate a 'Production Control' plan or plans, or amendments thereof, upon written petition, and with the approval of Pennsylvania producers of seventy-five per centum of the Pennsylvania output of any United States mineral resource industry located preponderantly within the Commonwealth, or to adopt and promulgate any such plan or plans in operation at the time of the enactment of this act with the sanction of the Pennsylvania producers of seventy-five per centum of the Pennsylvania output of such industry, and to administer or secure the cooperation of others, including State officers, producers' representatives or employees' representatives in any industry where there are general collective bargaining arrangements, in administering such plan or plans or amendments thereof upon a voluntary basis: Provided, however, that no production control plan or rules or regulations relating thereto shall apply to producers who are not petitioning producers or who do not otherwise assent to the production control plan promulgated and adopted.

"(b) A 'Production Control' within the meaning of this act is any system of regulated production in any industry as above defined which currently controls the daily, weekly or monthly volume of allowable production of said industry in Pennsylvania for the purpose of adequately supplying market demand, avoiding waste of mineral resources or the exploitation thereof without adequate return to the Commonwealth, her political subdivisions and people, protecting capital invested therein from unwise depletion and dissipation, promoting employment and security for the payment of wages and benefits to those employed in such industry and achieving other express purposes of the Commerce Law (1) by allocating or apportioning to each producer in the indutry a fair and equitable distributive portion of the total allowable production; (2) by providing for the adjustment of inequities in assigned distributive portions and for fair and equitable adjustments of distributive portions whenever transfers of mineral properties or facilities take place between or among producers based upon the position in the industry fairly and equitably attributable to such properties or facilities; (3) by providing for the admission under such plan of new operations and for the assignment of a fair and equitable distributive portion of the total allowable production to such operations; (4) [deals with standards of quality] (5) and also by establishing and providing for reasonable rules and regulations to effectuate such control plan.

"(c) [Deals with inspection for standards of quality]

"(d) [provides for compilation of statistics]

"(e) The department or agency administering any such production control plan, including the Production Control Plan for the Anthracite Industry heretofore promulgated and now functioning under the provisions of this act, shall make a report to each regular session of the General Assembly, showing, inter alia, the percentage of the output of the industry under such plan and the experience of the industry thereunder, and shall include therein any recommendations such agency may have with respect to further legislation which will be helpful in carrying out the purposes of this act.

"(f) No production control plan promulgated by the department under the authority of this act shall be continued, whenever the department, if it administers the plan, or the officers of the State, or a majority of such officers administering or assisting in the administration of any such plan, shall report to the Governor, and the Governor shall find that such plan no longer accomplishes the purposes of this act or no longer is in the public interest."

The Anthracite Committee also administers the Anthracite Standards Law, Section $3(12)$ (b) 4 and Section 3(12) (c) of the same act, but that is beyond the scope of this study. 
at the expense of the subscribing operators who pay in proportion to their companies' ratings on Schedule A,44 and it "may be amended in writing by producers whose aggregate percentages under Schedule A total not less than $75 \%$, with the approval of the Governor and the Anthracite Committee, excepting that Schedule A may be modified only as expressly provided herein." 45 One of the most legally significant features of the Plan is that it is entirely voluntary in nature both for the operators and for the state. Any operator may refuse to cooperate, and the Governor may abolish the whole plan on recommendation of the Department of Commerce or the officers of the state who participate in the Plan, if the Governor finds the Plan no longer to be in the public interest. ${ }^{46}$

Each Monday the Anthracite Producers' Advisory Board meets in New York City. ${ }^{47}$ This Board consists of fourteen sales managers, vicepresidents in charge of sales, and presidents of operating companies. They were elected by a meeting of all the cooperating producers for the life of the Plan or until successors are elected, seven being elected by a plurality vote of all producers and seven by votes weighted according to the tonnage ratings on Schedule A. A majority of the Board constitutes a quorum and a majority of any quorum may act. The official function of the Board is to "advise and make recommendations to the Executive Committee [of the Anthracite Committee] in respect to all matters covered by this Plan," including "advice and recommendations on production as related to prospective market requirements." 48 The actual function of the Board is to recommend the amount of production for the following week. Each week the cooperating producers are required to report to the Producers' Board and to the Anthracite Committee so as to reach both groups by Monday morning with figures showing production, sales, and inventory of the previous week as of Saturday noon. On the basis of orders and the weather (temperature) a prediction of demand for the entire industry, including non-cooperating producers, is made. This is corrected by inventories of unsold and stored coal wherever located and by taking into account the previous week's error in prediction. The resulting figure is then telephoned to the Anthracite Committee in Harrisburg.

The Anthracite Committee meets weekly in Harrisburg, also on Mondays. It consists of nine members, three each from state, operators and union: The Secretary of Commerce (Andrew J. Sordoni) as chairman; The Secretary of Mines (William J. Clements) as vice-chairman; and seven others appointed by the Governor, one a state officer (Randolph C. Ryder, Deputy Attorney General), three from a panel submitted by the cooperating producers (the presidents of Philadelphia and Reading Coal and Iron Co. [13.4\% of industry tonnage], Middle Eastern Coal Co.

44. Anthractie Production Control Plan art. VII (B).

45. Id. art. VII (C).

46. See note 43 supra.

47. Much of the information which follows was obtained by personal interview with persons involved in the origination and operation of the Plan.

48. Anthracite Production Control Plan art. II (C). 
[0.2\%], and Glen Alden Coal Co. [14.1\%]), and three from a panel submitted by the United Mine Workers Association (the presidents of the three district locals). ${ }^{49}$ Seven members constitute a quorum and any action requires the approval of seven members. ${ }^{50}$ Thus each of the three groups has a veto power, a right which for the state is the most important aspect of its control. The Committee is not a body for the arbitration of conflicting interests; in actual practice all decisions reached are made by unanimous vote. All three groups are interested in predicting demand, and each of the nine members is valuable only for his personal ability so to predict.

The actual function of the Committee is to set a production requirements figure for the whole industry. It has before it the same data as the Producers' Advisory Board (the prior week's production and present unsold inventory), in addition to the producers' estimate as to production requirements. The Committee changes the producers' figure about half of the time and its decision is always final.

When the Committee has set the "production requirements" for the week, the estimated production of the non-cooperating producers not on Schedule $A^{51}$ is subtracted; the remainder is then apportioned to each producer on Schedule A according to his percentage position. Those noncooperating producers who at one time were cooperators in the Plan have their percentage positions maintained on Schedule A. Each cooperating producer is then sent the figure for the industry as a whole and his individual proportion. ${ }^{52}$ The non-cooperating producers, of course, reap the greatest benefits from the Plan, but they produce only about $15 \%$ of the coal. ${ }^{53}$ Of this $15 \%, 10.09 \%$ is produced by those not on Schedule A. ${ }^{54}$

Schedule $A$ is the list of historical percentages of production reached by analysis of a base period before institution of the Control Plan. Since the capacity of many companies has decreased since Schedule A was drawn up, some companies do not reach their quotas. Although this may be compensated for in the following week for the industry as a whole, a new schedule, $B$, is being drawn up to reflect production capacity more accurately. When in any particular week a producer does not reach his quota, he may not in succeeding weeks make it up unless the loss was the

49. The Governor has the power to remove any member "for inability to act for any reason, inefficiency, neglect of duty or misconduct in office." ANTHRACITE Production Control Plan art. I (C).

50. Provision is made for an Executive Committee composed of the Secretary of Commerce (or the Secretary of Mines if delegated by the former), a producer, and a union representative. Anthracite Production Control Plan art. I (D).

51. About $85 \%$ of the anthracite producers are cooperating with the Plan today. The production of the other $15 \%$ does not change significantly and is reported to the Anthracite Committee monthly.

52. Antmracite Production Control Plan art. III (A).

53. This information was obtained in a personal interview with $\mathrm{Mr}$. D. L. Corgan, Secretary of the Anthracite Committee.

54. Anthractie Commitiee, Commerctal Production of Anthracite by ComPANIES (1951). 
non-negligent result of one of certain enumerated causes and the Executive Committee approves the succeeding increase. ${ }^{\mathbf{6 5}}$

A report must be made by the Committee to every regular session of the Pennsylvania General Assembly. ${ }^{56}$ The report of July 25, $1951{ }^{57}$ indicated that a fall in demand had caused the industry to discontinue the unlimited production which had been allowed from 1942 to 1948 . Large inventories protected the public against any sudden turn in the weather which would have created a sudden demand. Price stability was maintained when capacity was far greater than demand. The 1953 report ${ }^{68}$ indicates some lack of cooperation because of dissatisfaction with Schedule A, but also indicates that Schedule B is being worked on. A great loss of business in the past two years, especially to oil and gas, is reported.

Although the purpose of the Plan is to set production according to demand, neither the statute nor the Plan confines the delegated authority to that purpose. The statute authorizes a "Production Control" plan and defines it as "any system of regulated production . . . for the purpose of adequately supplying market demand, avoiding waste of mineral resources . . protecting capital from unwise depletion and dissipation, promoting employment and security for the payment of wages and benefits. . . "50 The first enumerated purpose, that of adequately supplying demand, may very well be in conflict, particularly in a declining industry, with the third and fourth purposes, those of protecting invested capital and promoting the welfare of the workers. Adequately supplying demand may require higher production while protection of capital (operators) and the workers (union) may require lower production to stabilize the industry further. When such a conflict occurs it is the duty of the regulatory body, which in this case is the Anthracite Committee, to make the choice.

The Production Control Plan is also vague in its definitions of the delegated authority. The stated duty of the Anthracite Committee is "to administer the Production Control Plan herein provided for, in accordance with its intent and purposes." 60 Presumably the intent and purposes referred to are those in the statute. The duties of the Producers' Advisory Board are to "advise and make recommendations to the Executive Committee in respect to all matters covered by this Plan." Further on it is suggested that the Board should make recommendations of production "as related to" market requirements. ${ }^{61}$ This is not worded as a strict

55. Anthracite Production Control Plan art. V (I), (J). (Causes are: local strikes, fire, flood, explosion, squeeze, machinery breakdown, electrical breakdown, and shortage of railroad cars.)

56. PA. Stat. AnN. tit. 71, $\$ 1709-3(12)$ (e) (Purdon Supp. 1952).

57. Anthracite Commitree, Report to the General Assembly of CommonWEALTH OF PA. (July 25,1951 ).

58. Anthracite Comimitee, Report to the General Assembly of Conmonwealth of PA. (June 18, 1953). This is the latest report.

59. Pa. Stat. Ann. tit. 71, §1709-3(12) (b) (Purdon Supp. 1952).

60. Anthracite Production Control Plan art. I (D).

61. Id. art. II(C). "In respect to advice and recommendations on production as related to prospective market requirements, the Board shall take into considera- 
requirement, nor is the phrase "as related to" capable of any confined definition. Conceivably the Committee could set production far below demand in order to protect capital and labor as long as the difference was not so great as to be "unrelated" to demand. As far as may be ascertained the Committee and Board do confine themselves to setting production at the level of demand less excess inventory. The level of demand, however, is determined by the price at which the coal is being sold. As a result, the production figure will serve to maintain the existing price level. Thus production control is really a form of price control.

The weekly calculations are not open to public examination, nor are any specific findings reported. ${ }^{62}$ Under such circumstances, it is possible for the regulatory body to do much as it pleases, particularly in light of its broad delegated authority. It may also be noted that since the controls are voluntary it is necessary to obtain the consent of the industry in order to make any changes in the regulation of the industry. ${ }^{03}$ Potentially, this is counterbalanced by the power of the Governor to abolish the whole program in the public interest. ${ }^{64}$

The present law gives the industry much greater freedom than the bills introduced in $1938^{65}$ which would have set prices and introduced the state as a competitor of private enterprise; it gives even greater freedom than the 1939 bill ${ }^{66}$ which proposed a salaried three-man commission entirely independent of the operators, required licensing of all operators and denial of licenses to financially unsound new operations, and fixed production in a manner similar to the present law to maintain a reasonable balance between production and demand. That plan was mandatory, enforced by fines, and expired in four years. Neither the 1939 bill nor the present Plan takes price into official consideration.

\section{Effect of the Plan on Prices, Profits, and Costs}

The purpose and effect of the Plan is to raise prices by decreasing the available supply which will compete for the demand. That is the purpose of all efforts at stabilization in the face of cutthroat competition. High cost producers who would be bankrupted by the uncontrolled operation of competition are enabled to stay in business by the higher prices charged to the consumer. Senator Watkins in praising the plan during its consideration by the legislature stated that companies which had been operating

tion inventories of unsold anthracite in cars at mines or other points designated for such purposes by railroad companies, at tidewater piers and lake ports, en route to piers or ports, and anthracite in storage, wherever located."

62. Compare the California Agricultural Prorate Act, CAL. GEN. LAws act 143a (Deering 1944), to be discussed infra. Section 7 of that act provides: "A full and accurate record of business or acts performed or of testimony taken in pursuance of the provisions of this act shall be kept and be placed on file in the office of the director, which records shall at all times be open to any interested person."

63. Anthracte Production Control Plan art. VII (C).

64. Pa. Stat. AnN. tit. 71, $\$ 1709-3$ (12) (f) (Purdon Supp. 1952).

65. See text at note 27 supra.

66. See text at note 30 supra. 
at a loss were then making a profit. ${ }^{67}$ The Senator named three companies and said that a great many others would not be operating were it not for production control. He predicted that many collieries would reopen if the trend toward stabilization continued. ${ }^{68}$

Table IV shows that prices jumped in January 1940 to $\$ 9.50$ per ton from $\$ 9.15$ in December 1939, perhaps in anticipation of the Plan, which became effective January 30, 1940. The average price for the uncontrolled year of 1939 was $\$ 9.14$ while for the controlled year of 1940 it was $\$ 9.55$. These published prices do not indicate the even greater fluctuations at tidewater markets. ${ }^{69}$ The schedule of bituminous prices, for which minimums were set under federal regulation, ${ }^{70}$ shows a decline of $\$ 0.01$ from 1939 to 1940 . The general war boom, which could be expected to affect bituminous, an industrial fuel, more than anthracite, largely a domestic fuel, did not occur in the coal industry until 1941. ${ }^{71}$ Thus the Anthracite Production Control Plan was probably instrumental in raising prices in 1940.

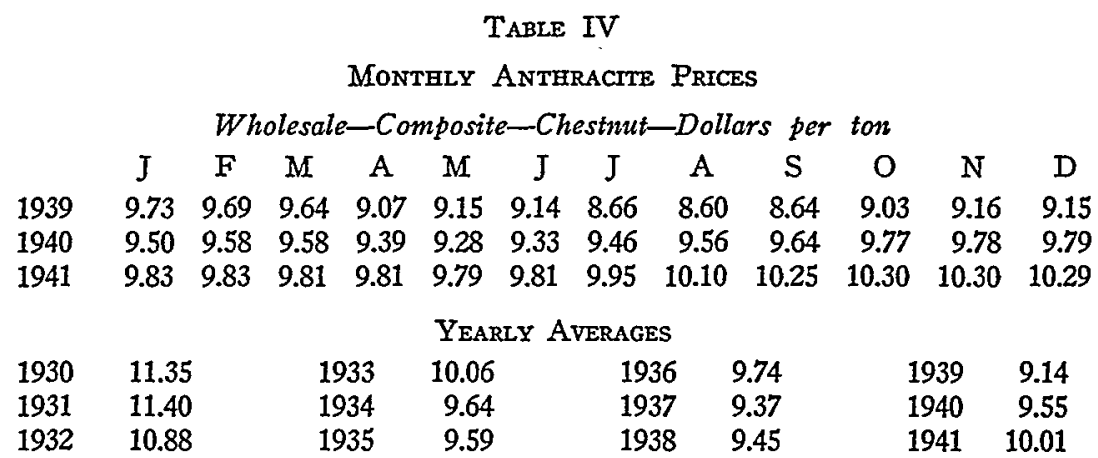

Monthly Bituminous Prices

Wholesale-Composite-Mine Run-Dollars Per Net Ton

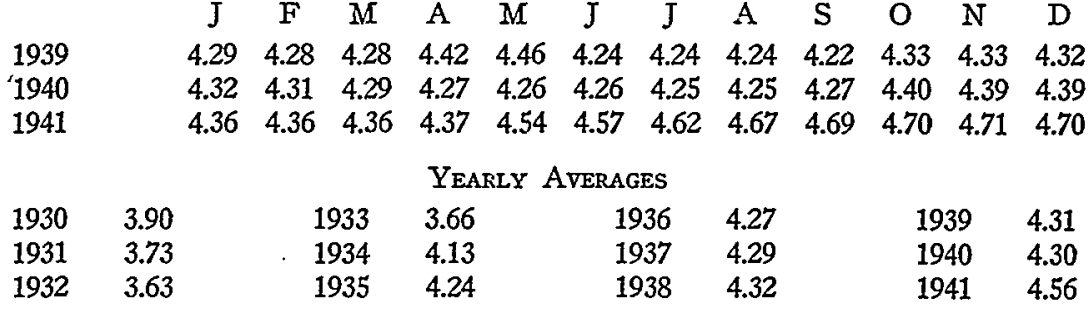

from Standard and Poor, Trade and Securities 180 (1949) and Bureau of Labor Statistics, Wholesale Prices (June and Dec. 1939).

67. He noted that there had been ten companies in three counties which had suffered bankruptcies during the period before the institution of controls. According to the Senator, from the inauguration of the plan to the time of the debate in the legislature (less than sixteen months), not a single bankruptcy had occurred. 24 PA. LEGIS. J. 4497 (1941).

68. Id. at 4497-8.

69. Glen Alden Coal Co., 1941 Annual Report 1.

70. 50 Stat. 72 (1937) (Bituminouis Coal Act of 1937).

71. Philadelphia and Reading Coal and Iron Co., 1939 Annual Report 10. 
A study of the reports of four of the largest anthracite companies comprising about $40 \%$ of the industry's production indicates a substantial improvement in financial conditions in 1940. The Philadelphia and Reading Coal and Iron Co., which had been operating at deficits of from $\$ 1,000,000$ to $\$ 4,500,000$ for each of the previous four years, achieved a profit of $\$ 747,000$ in $1940^{72}$ and admitted that the Plan had been beneficial. ${ }^{73}$ The Lehigh Valley Coal Corporation, which had had net operating deficits of over $\$ 1,000,000$ for each of the three preceding years, in 1940 enjoyed a profit of $\$ 265,000$ while sales and production dropped. ${ }^{74}$ It ascribed to the Anthracite Plan "a satisfactory measure of success." 75 The Lehigh Coal and Navigation Co., which had had deficits of from $\$ 500,000$ to $\$ 1,500,000$ (before general and administrative expenses) for the preceding four years, enjoyed a profit (before the same expenses) of $\$ 151,000$ for 1940 while production and tons sold declined. ${ }^{78}$ The Glen Alden Coal Co., which had operating income of $\$ 1,200,000$ to $\$ 2,600,000$ for each of the three preceding years, enjoyed operating income of $\$ 4,900,000$ in 1940 while tons mined and tons sold each declined about $7 \%$ from the preceding year. ${ }^{77}$ That company reported: "Much of the improvement in operating results can be attributed to this Program for while published prices were generally the same as in 1939, price-cutting was less severe and published prices were more nearly realized." 78 Thus, in the first year of the Plan three of the four companies increased their net income substantially while their sales and production declined. The fourth profited for the first time in five years. The first indication that the World War II boom had hit the industry did not appear until 1941. ${ }^{79}$ Indeed, any war boom at this time would have increased production which for 1940 was 2000 tons less than for 1939. From the standpoint of the companies, at least, the Plan has been successful.

\section{The Legality of the Plan}

The Plan cannot be seriously challenged under state law, since it was provided for by the state legislature and since the state courts find no difficulty in sustaining the constitutionality of acts of legislature controlling

72. Moody's Industrials 1711 (1941).

73. Philladelphia and Reading Coal and Iron Co., 1939 Annual Report 10; 1940 ANNuAL Report 10.

74. Moody's Industrials 596 (1941).

75. Lemigh Valley Coal Corporation, 1940 Annual Report 2.

76. Moody's Industrials 2489 (1941). Lehigh Coal ascribed its 1940 success to "reduction in royalty and interest payable, lower costs generally, and higher average income per ton of coal sold." LEHIGH COAL AND Navigation Co., 1940 ANNUAL REPORT 27. In the preceding year "unusual competitive conditions in the Industry forced prices to extremely low levels." LEHIGH COAL AND NAVIGATION Co., 1939 AnNual Report 29.

77. Moody's Industrials 165 (1941).

78. Glen Alden Coal Co., 1940 Annual Report 1.

79. Glen Aiden Coal Co., 1941 Annual Report 1. 
industries of a large and public nature..$^{80}$ Whether the Plan is subject to the jurisdiction of the national government depends on the breadth of the commerce clause. Although state limitation to daily demand of oilwell production which was immediately shipped in interstate commerce was in 1932 held valid as not "part of interstate commerce," 81 in 1942 Wickard $v$. Filburn ${ }^{82}$ extended the federal jurisdiction to production controls having a substantial economic effect on interstate commerce. In Wickard the Federal Government was allowed to limit grain production destined for consumption on the producer's farm on the grounds that farmers' purchasing or refraining from purchasing extra grain affected the interstate market price. Since the limitation on coal production has been shown to affect the interstate market price, ${ }^{83}$ any coal production control is within the regulatory power of the Federal Government. ${ }^{84}$

Restrictions on interstate commercial activity are controlled by two different legal sanctions, depending on the source of the restrictions. Private restraints of trade are subject to anti-trust prosecution. ${ }^{85}$ Burdens on interstate commerce by a state are subject to the bar of the commerce clause of the Constitution. The commerce clause is not directly applied to private restrictions because the Sherman Act is available, but it may be questioned whether the Sherman Act should not be applied to state action since the evil economic effects of restraints on commercial activity are no less severe when perpetrated by a state than when they result from private action. Nevertheless a state legislature ostensibly represents all of the strata of society in its domain, and it may be assumed that all have a chance to voice their opinions in the consideration of legislation. ${ }^{86}$ Because of this representation, there is justification for requiring a greater degree of interference with production on the part of a state than on the part of a private person, before the Federal Government is allowed to intervene. The Supreme Court has held in Parker v. Brown ${ }^{87}$ that the Sherman Act could

80. See, e.g., Scranton v. Public Service Commission, 268 Pa. 192, 110 At1. 775 (1920); Commonwealth v. Vrooman, 164 Pa. 306 (1894). But cf. Hertz Drivurself v. Siggins, $359 \mathrm{~Pa}$. 25, 58 A.2d 464 (1948).

81. Champlin Refining Co. v. Commission, 286 U.S. 210 (1932).

82. 317 U.S. 111 (1942).

83. See text following note 68 supra.

84. Cf. Sunshine Coal Co. v. Adkins, 310 U.S. 381 (1940).

85. E.g., 15 U.S.C. $\$ \S 1,2$ (1946) (Sherman Act); 15 U.S.C. $\$ 12-27$ (1946), as amended, 15 U.S.C. $\$ 17-21$ (Supp. 1952) (Clayton Act).

86. Whether this assumption is valid may be judged by perusal of the text at notes 27 and 41 supra.

87. 317 U.S. 341 (1943). State regulation of prices of commodities, regulation of which constitutes a per se violation when done by private parties (United States v. Socony-Vacuum Oil Co., 310 U.S. 150 (1940)), has been approved under the commerce clause by the Supreme Court without reference to the Sherman Act. Nebbia v. New York, 291 U.S. 502 (1934). See also, Cities Service Co. v. Peerless Co., 340 U.S. 179 (1950) (natural gas). State restrictions on production of milk for other states have been disapproved under the commerce clause without reference to the Sherman Act. Hood \& Sons v. Du Mond, 336 U.S. 525 (1949); cf. Suni-Citrus Products Co. v. Vincent, 72 F. Supp. 740 (S.D. Fla. 1947), (where state regulation of prices in a patent pool was approved partly under Parker $v$. Brown), rev'd on other grounds, 170 F.2d 850 (5th Cir. 1948). 
not be applied to state regulation of the marketing of raisins on the basis of market requirements, finding that neither the Sherman Act nor its history suggest the purpose of restraining a state. The Court distinguished situations where the state might authorize or become a participant in a private combination for restraint of trade. ${ }^{88}$

Whether the Sherman Act applies to the Anthracite Plan, therefore, depends on whether the Anthracite Plan presents the same kind of state action as was present in the Parker case. The Anthracite Plan was inaugurated by the agreement of Pennsylvania's governor and the United Mine Workers ${ }^{89}$ with the operators. The agreement of the governor did not bring the Plan within a strict reading of the Parker rule, since the regulation classified as state action by the Supreme Court in Parker $v$. Brown "derived its authority and its efficacy from the legislative command of the state and was not intended to operate or become effective without that command." (Emphasis added.) ${ }^{00}$ Furthermore, where the legislature has indicated a conscious choice of policy, as it did here in rejecting a stricter production control plan, the governor would seem to have no power to contract with private parties against the legislature's will. ${ }^{91}$ As a result, the governor's cooperation was insufficient to exclude from the operation of the Sherman Act a plan which might otherwise have been a violation. ${ }^{22}$ A more difficult question is whether the later intervention of the legislature took the Plan out of the scope of the Sherman Act. A comparison of the important aspects of the Plan with the California statute and program considered in the Parker case will indicate whether the Anthracite Plan derives its "authority and efficacy from the legislative command of the state" in a similar manner.

88. Union Pacific R.R. v. United States, 313 U.S. 450 (1941); Northern Securities Co. v. United States, 193 U.S. 197, 344-7 (1904). The possibility that the instant plan falls within the doctrines of these cases is discussed in text at note 109 infra.

89. The co-operation of the United Mine Workers may have originally been obtained at least partly to avoid the Sherman Act since union activities had been exempted from the operation of that act. United States v. Hutcheson, 312 U.S. 219 (1941). In 1945, however, the Supreme Court held that a union's participation in a combination of businesmen to eliminate competition could not obviate the application of the antitrust laws. Allen Bradley Co. v. Local 3, I.B.E.W., 325 U.S. 797 (1945).

$$
\text { 90. } 317 \text { U.S. } 341,350 \text { (1943). }
$$

91. Lukens v. Nye, 156 Cal. 498, 105 Pac. 593 (1909); cf. Youngstown Sheet \& Tube Co. v. Sawyer, 343 U.S. 579 (1952) in which the President took possession of and managed the steel companies because of an emergency despite the fact that Congress had consciously rejected the use of such methods in the Labor Management Relations Act.

92. Whether the plan would violate the Sherman Act without the State's participation is discussed infra. See text at note 111 infra. As to legality of the Plan by the governor's action alone, compare 63 STAT. 391 (1949), 70 U.S.C. $\$ 488$ (Supp. 1952). Application of anti-trust laws to buyers of government property of a value of over $\$ 1,000,000$ cannot be prevented by the rendering of an unfavorable advisory opinion to the General Services Administration by the Attorney General as to whether the disposition would create a situation inconsistent with the antitrust laws. 
The California system ${ }^{93}$ allows the inauguration of marketing controls for various agricultural commodities if $65 \%$ of the producers and the owners of $51 \%$ of the producing acreage approve; $; 94$ controls are enforced against all producers by penal sanctions ${ }^{95}$ and can be terminated only by expiration or on the application of $40 \%$ of the producers and the owners of $40 \%$ of the acreage. .96 The Anthracite Plan had to be approved by $75 \%$ of the tonnage of the industry, and since it is voluntary, it sets up no requirements for withdrawal. In each case the inauguration of the controls has been left to the industry; the California statute imposes more control by reason of penal sanctions until the $40 \%$ withdrawal requirement is met. However, state control is necessary to eliminate any Sherman Act problem only where there are restraints of commerce on monopolizing, and in Pennsylvania $100 \%$ of those who limit their production are controlled by the state, which has a veto power over their quotas. Those who do not cooperate are not in restraint of trade and therefore do not need state control. The California statute requires before a plan is approved that it be shown that it will not result in unreasonable profits to the producer, ${ }^{97}$ thus safeguarding prices to the consumer; whereas such a safeguard is lacking in Pennsylvania where no consumers are represented in the determination of the quotas. Part of this difference is explicable by the fact that the Anthracite Plan was directed at a single, obviously depressed industry whereas the California statute is applicable to many commodities, and a finding of instability in the commodity intended to be regulated must be made before regulation can be imposed.98

Under the California statute, and the raisin plan in particular, production was not controlled, but the state undertook to market $70 \%$ of the crop and to make loans.99 In Pennsylvania each producer is limited in the amount he can mine. Thus in California sales and financing are controlled whereas in Pennsylvania the Plan sets a figure for production. These are, however, only two different means of restricting supply at the source. Regarding standards of regulation, California explicitly requires that marketing be adjusted to market demand ${ }^{100}$ while the Pennsylvania statute requires production be regulated for four different and conflicting purposes. ${ }^{101}$ In actual operation the Pennsylvania plan does in all probability, however, limit itself to market demand.102

The most significant and determining kind of state control is in the administration of both plans. The California statute requires that the plan

93. Cal. Gen. Laws act 143a (Deering 1944).

94. Id. § 16 .

95. $I d . \S 22.5$. There is also provision for civil liability. Id. $\S 25$.

96. $I d . \S 23$.

97. Id. $\S 10(6)$.

98. Id. $\S 10(2)$.

99. Id. §19.1(c), § 26 .

100. Id. $\$ 19.1(\mathrm{e})$.

101. See text at note 59 supra.

102. See text following note 61 supra. 
be approved by an Advisory Commission of nine; six producers, one consumer representative, one "handler," and the Director of Agriculture. ${ }^{103}$ This Commission also approves the Director's selection of a program committee nominated and drawn from the producers; ${ }^{104}$ the program committee formulates the marketing programs subject to commission approval ${ }^{105}$ and administers the prorate program subject to the approval of the Director of Agriculture. ${ }^{106}$ The Anthracite Plan is administered by nine men, with the governor, labor and industry each appointing three. Seven are needed to approve any motion or quota. Furthermore, the governor can abolish the Plan at any time. ${ }^{107}$ Each plan, therefore, has the state government in control with a veto power over the immediate administration of the plan. If state action consists of control by elected representatives, each plan is equally state action. Questions of voluntariness, consumer representation and state handling of the product would seem less significant than the fact that the Plan was passed by the legislature and that the elected governor of Pennsylvania can veto all regulation through his appointees. In addition, the legislature is presented with a report each year; if it became dissatisfied, the legislature could, of course, abandon the Plan entirely.

The possibility that the instant Plan might be excluded from the state action category as expounded by Parker $v$. Brown must be considered. The question here is whether the state has become a participant in a private combination for restraint of trade so as to include the combination in the purview of the federal anti-trust acts. The two cases distinguished by the Court in Parker involved defenses by corporations: that a state had granted the corporate charter and therefore the defendant corporation was immune to anti-trust prosecution; ${ }^{108}$ and that a city rather than defendant railroad granted subsidies to businesses to assume leases in defendant's new terminal, ${ }^{109}$ therefore rendering defendant immune. But in the former case, it was held that the corporate charter could not be interpreted to authorize the subsequent development of restraint of trade; in the latter case, that the subsidies were authorized not by a state but by Kansas City, which is a far less representative unit, and scarcely represented the interests of other

103. Cal. Gen. Laws act 143a, 33 (Deering 1944).

104. Id. § 15 .

105. Ibid.

106. Id. $\$ 22$.

107. See note 43 supra.

108. Northern Securities Co. v. United States, 193 U.S. 197, 332, $344-7$ (1904); cf. Schwegmann Bros. v. Calvert Distillers Corp., 341 U.S. 384 (1951). (A state fair trade statute, which bound nonsigner retailers to the prices of contracts made between producers and other retailers purportedly under the Miller-Tydings exemption to the Sherman Act, 15 U.S.C. \$ 1 (1946) was held to be not within the exemption which applied only to signers. The argument that a state is not subject to the Sherman Act was not dealt with by the Court, but could have been distinguished on the grounds that the state failed to regulate prices under the contracts as well as on the stated grounds that Congress did not intend to cover nonsigners by the Miller-Tydings Act.)

109. Union Pacific R.R. v. United States, 313 U.S. 450 (1941). The statute construed was the Mann-Elkins Act prohibiting rebates by carriers to shippers. 32 Stat. 823, 847-8 (1903), as amended, 49 U.S.C. \$41-5 (1946). 
railroads. ${ }^{110}$ Moreover, subsidies, which were initiated if not paid by defendant, discriminated against other railroads which served the city area. In neither case was there any state administration of a continuing program. Furthermore, in the Anthracite Plan the state has approved the very practices carried on and no provisions discriminatory against any producers exist. In fact, producers who do not take part in the plan probably benefit most since they have the advantage of price increases resulting from the limited production of the members, without restricting their own output.

Should the Anthracite Plan by reason of its private origin be considered not state action within the scope of Parker, the fact that from 80 to $85 \%$ of the industry "cooperates" in the Plan might well make it illegal as a monopoly under Section 2 of the Sherman Act, ${ }^{111}$ particularly since its control of production affects prices. ${ }^{112}$ Under Section 1, a combination to control production for the purpose of controlling supply or prices on an interstate market is an illegal restraint of trade. ${ }^{113}$ Clearly the Anthracite Plan has no other purpose than to control supply and thereby stabilize prices.

On the other hand, during the depression, Appalachian Coals, Inc. $v$. United States ${ }^{114}$ upheld under sections 1 and 2 the creation of a unified sales agency of $74 \%$ of the bituminous coal producers in the Southern High Volatile Bituminous Field despite a "stabilizing" effect on prices. This holding was basically on the theory that the agency would still be faced with effective competition from coal outside the agency. A contributing reason was the recognition of competition in the broader market of coal and coal substitutes; such a competition and market is likewise present in the anthracite situation; in fact it is the very cause of anthracite's precarious situation. Under the "rule of reason" as developed in Appalachian 115 the Plan might be legal without state action, but that case indicates that there was no control of production. And furthermore, recent cases cast doubt on the continuing validity of Appalachian. Judge Learned Hand has indicated that the Appalachian case has been discredited." "It is settled, at least as

110. The other railroads had their principal terminal in Kansas City, Missouri, across the river. "But the promotion of civic advancement may not be used as a cloak to screen the granting of discriminatory advantages to shippers." Union Pacific R.R. v. United States, 313 U.S. 450, 465 (1941).

111. See United States v. Aluminum Co. of America, 148 F.2d 416 (2d Cir. 1945 ) (in which Judge Hand designated $90 \%$ control as a clear monopoly).

112. Id. at 424 .

113. Hartford-Empire Co. v. United States, 323 U.S. 386 (1945) ; Coronado Coal Co. v. United Mine Workers, 268 U.S. 295 (1925); American Column and Lumber Co. v. United States, 257 U.S. 377 (1921) ; cf. United States v. SoconyVacuum Oil Co., 310 U.S. 150 (1940) (where private companies continued buying "distress" gasoline to support the market price as had once been authorized under the NRA) ; Standard Oil Co. v. United States, 283 U.S. 163, 169 (1931); see also HandLer, Federal Antitrust Laws (TNEC Monograph 38, 1941).

114. 288 U.S. 344 (1933).

115. Cf. United States v. United States Steel Corp., 251 U.S. 417 (1920) ; Board of Trade of Chicago v. United States, 246 U.S. 231 (1918).

116. United States v. Aluminum Co. of America, 148 F.2d 416, 427 (2d Cir. 1945) citing United States v. Socony-Vacuum Co., 310 U.S. 150, 220-4 (1940). 
to $\S 1$, that there are some contracts [referring to price-fixing] restricting competition which are unlawful, no matter how beneficent they may be; no industrial exigency will justify them; they are absolutely forbidden." 117

Assuming, however, that the Anthracite Plan is state action on the basis of the veto power belonging to the three state representatives on the Anthracite Committee, the question remains whether the state action is valid under a direct application of the commerce clause. In 1932, Champlin Refining Co. v. Corporation Commission ${ }^{118}$ held that state regulation of production of oil destined out of state was not regulation of interstate commerce, but the distinction there drawn between manufacture or production of a commodity and the subsequent interstate transportation of it was maintained only as an alternative holding in Parker $v$. Brozen in 1943,119 and has been discarded when raised as a defense to federal regulation. ${ }^{120}$ Since $69.94 \%$ of anthracite was shipped out of Pennsylvania in 1951-52,121 control of anthracite production must at least be regulation affecting interstate commerce.

Nevertheless, states may, in the absence of conflicting federal regulation, regulate that part of interstate commerce which is peculiarly adapted to local regulation and diversity of treatment. ${ }^{122}$ If the regulation discriminates against interstate commerce, it will be invalid; ${ }^{123}$ if it only burdens interstate commerce without giving intrastate commerce a greater advantage, the Court's usual approach has been to balance the competing interests of nation and state. ${ }^{124}$ The Anthracite Plan burdens interstate commerce by raising the price of coal to the consumer, but since the price is no different for the out of state consumer than for the Pennsylvania consumer, there is no discrimination; therefore, it is a matter of weighing the competing state and national interests. Parker $v$. Brown held that the prorationing of the raisin crop to stabilize the market was "peculiarly within the province of the state" despite the fact that it raised interstate prices and curtailed interstate shipments (95\% of the crop was consumed

117. United States v. Aluminum Co. of America, 148 F.2d 416, 427 (2d Cir. 1945). See United States v. Trenton Potteries Co., 273 U.S. 392 (1927) (unconditionally condemning contracts fixing prices).

118. 286 U.S. 210 (1932).

119. 317 U.S. 341, 362 (1943), 41 Mrcr. L. Rev. 968 (1943). Cf. Dean Milk Co. v. City of Madison, 340 U.S. 349 (1951) (municipal ordinance requiring all milk sold in Madison to be pasturized within five miles of the city held unconstitutional); Toomer v. Witsell, 334 U.S. 385 (1948) (statute requiring all shrimp boats fishing in South Carolina waters to dock in South Carolina held unconstitutional).

120. Wickard v. Filburn, 317 U.S. 111 (1942); United States v. Darby, 312 U.S. 100 (1941). (1953).

121. Anthracite Institute, Manual of Statistical Information Table 16

122. California v. Thompson, 313 U.S. 109 (1941); Cooley v. Board of Port Wardens, 12 How. 299 (U.S. 1851).

123. Morgan v. Virginia, 328 U.S. 373 (1946).

124. Toomer v. Witsell, 334 U.S. 385 (1948) ; Southern Pacific R.R. v. Arizona, 325 U.S. 761 (1945). 
elsewhere).$^{125}$ Thus, the state interest prevailed in a situation very similar to the Anthracite Plan. However, Parker is distinguishable from the Anthracite Plan on several grounds. In California production itself was not limited and there also existed at the national level similar programs which embodied provision for cooperation with the states by federal authorities. ${ }^{126}$ Under the California statute at least some consideration is given to the out of state consumer interest by denying excessive profits to the producers. ${ }^{127}$ The fact remains, however, that Parker did find the production and marketing problems to be local.

What the Court overlooked in Parker and what is even truer in Pennsylvania is that the consumers of raisins and coal respectively, are not in fact represented in the state legislatures. The most significant fact is that $69.94 \%$ of the consumers of anthracite are not represented in the Pennsylvania legislature, while over $95 \%$ of anthracite production is. Even if the consumers had been $100 \%$ opposed to the Plan, they could not have easily protected themselves. Consumers are never able to organize so effectively as the labor and management lobbies, a fact indicated by the failure of a single legislator to oppose passage of the amendment to the Commerce Law of Pennsylvania which authorized the Plan. The Plan itself was not open to question by any consumer groups at least until its ratification by the Pennsylvania legislature, which was more than a year after it was put into effect. Unless the Supreme Court is willing to declare state acts of this type unconstitutional, the way is opened to industries located predominantly in one state to obtain legislative permission for regulation which would otherwise violate the Sherman Act. On the other hand, if all state acts which affect citizens of other states are invalid, little is left to a state's regulation of its economic affairs. But if the national economic policy is to encourage competition, abrogation of that policy should be allowed only when all interested parties have at least the possibility of being represented substantially in proportion to their numbers. Present law as manifested by the Parker case seems only to prevent the states from giving blanket unsupervised permission to restrict competition, or from discriminating among private concerns.

The weakness of the Pennsylvania statute and the Anthracite Plan in not strictly limiting the authority of the Anthracite Committee to the right to set production at demand has already been shown. ${ }^{128}$ It is clear that the Plan was devised by the operators and union to support a declining industry and lessen the severity of competition. It was put into effect by a state governor without legislative approval eight months after the legislature had rejected a more stringent plan; the legislature approved a system which had been in operation for fifteen months and which without legislative

125. 317 U.S. 341,367 (1943).

126. 50 StAT. 246 (1937), 7 U.S.C. $\$ 608 \mathrm{c}$ (1946) (Agricultural Marketing Agreement Act of 1937); 52 STAT. 31 (1938), 7 U.S.C. $\$ 1281$ (1946) (Agricultural Adjustment Act of 1938).

127. Cal. Gen. Laws act 143a, $\S 10(6)$ (Deering 1944).

128. See text at note 59 supra. 
approval would have been of dubious legality. ${ }^{129}$ When consumers are as illrepresented as they were in the passage, structure, and operation of this Act, it would seem that the Parker doctrine should not be applied. ${ }^{130}$ Whether or not state-wide production control is the best method of reviving a declining industry in terms of the industry's economic situation is another matter.

\section{Alternatives and Evaluation}

There is no doubt that the anthracite industry is a sick one. The question is what economic policy is best to save, or "stabilize," that industry if, indeed, it should be saved. Several suggested policies will be outlined: production control, the present system; unrestricted price competition, similar to pre-production plan conditions; private ownership under one corporation; ${ }^{131}$ regulation as a public utility; ${ }^{132}$ and public ownership. ${ }^{133}$ These alternatives must be evaluated not only from the standpoint of benefit to the industry but also with reference to national economic and legal considerations.

The Production Plan.-Interviews with individuals taking part in the Plan disclose that a number of advantages have been gained as a result of the production controls. Employment in the stricken communities increased, although, even with the Plan, the industry continues to decline. ${ }^{134}$ Mine safety standards are raised because operators do not have to cut costs to the bone and because there are fewer unemployed miners forced to bootleg on their own without adhering to state safety regulations. Quality may be increased because pressure of low prices is not so great. Conservation is promoted because higher prices reduce the necessity to mine only the most accessible coal and leave the rest. ${ }^{135}$ The Plan provides protection for the capital investment of each company, which is especially important where the investment is in mines which are less convertible to different uses than are factories. Finally, the mines are kept open in case of a national emer-

129. See text following note 111 supra.

130. See Southern Pacific R.R. v. Arizona, 325 U.S. 761 (1945) in which Mr. Chief Justice Stone speaking for the Court said, "In applying this rule [that the states do not have authority to impede interstate commerce] the Court has often recognized that to the extent that the burden of state regulation falls on interests outside the state, it is unlikely to be alleviated by the operation of those political restraints normally exerted when interests within the state are affected." Id. at 767 n.2.

131. Glenn O. Kidd, now president of Lehigh-Navigation Coal Co., speech to joint meeting of Greater Philadelphia Fuel Conference and Philadelphia Coal Club, March 11, 1953.

132. See report of the Anthracite Coal Industry Commission, May 15, 1937, 21 Pa. Legrs. J. 7918 (1937).

133. Ibid.

134. Philadelphia Evening Bulletin, Nov. 19, 1953, p. 4, col. 5; ANTHRACITE Committee, Report to the General Assembly of Commonwealte of PA. (June 18, 1953); Hard Times in Hard Coal Country, Busrness WeEk Mar. 22, 1952, p. 108. 135. Report of the Anthracite Coal Industry Commission, 21 PA. LEgrs. J. 7917 (1937). 
gency ${ }^{136}$ reopening a closed mine to meet emergency demands would be complicated both by the labor problem and by the difficulty of removing accumulated water.

Because of geological upheavals and faults, mining in the Southern and West Middle fields is more costly and less adaptable to mechanization than the Northern and East Middle fields. ${ }^{137}$ Therefore, should it be desirable for the above reasons to keep all of the mines operating, protection by controls is a principal method to allow these naturally higher cost operations to continue. Furthermore, in a declining industry such as anthracite, free competition tends to be unusually severe as each company fights to retain its market. This has a tendency to cause losses as in 1938 and 1939 until enough operators discontinue to allow prices to rise again. Criticism of the Plan on the grounds that it raises prices is partially met by the fact that competitive fuels prevent too great an exploitation of this opportunity. Perhaps the greatest advantage of the Plan is that it retards business failures, preventing severe economic and human dislocations. The Plan's validity under the Sherman Act and the problems of burdening interstate commerce have already been demonstrated.

Unrestricted Competition.-Competition has always been the instrument of free enterprise for the regulation of price and investment. Cutthroat competition (where even the most efficient producers operate at a loss) means only that too much is being produced; marginal producers who cannot meet price and quality standards are eliminated. Traditionally, the function of investors has been to absorb this shock, just as they reap the profits when production is below demand. That the investor made a mistake in investing is no reason to preserve him. It must be acknowledged that there is a danger that mines of a responsible producer driven out by competition will be reopened by an operator who will compete on the basis of costs reduced by the payment of non-union wages, by sacrifice of the quality of his product and the safety of his miners and by mining only the coal easiest to mine. Any achievement of price competition must, therefore, be accompanied by strict maintenance or improvement of the present quality controls (which the operators themselves initiated) and safety standards.

When production is artificially limited costs and prices both increase. ${ }^{138}$ Limiting production to demand guarantees the high cost producer a market

136. Further description of the problems of coal mining and the benefits of stabilization may be found in H.R. REP. No. 1800, 74th Cong., 1st Sess. (1935); H.R. REP. No. 294, 75th Cong., 1st Sess. (1937); SEN. ReP. No. 252, 75th Cong., 1st Sess. (1937); Hearings before subcommittee of Committee on Ways and Means on H.R. 8479, 74th Cong., 1st Sess. (1935); Hearings before subcommittee of Committee on Interstate Commerce on S. 1417, 74th Cong., 1st Sess. (1935).

137. Evan, Analysis of the Decline of the Anthracite Industry (unpublished thesis in $\mathrm{U}$. of $\mathrm{Pa}$. Library, 1950).

138. See text at note 69. supra. The magnifying effect, of production control on costs of production is evidenced by the protests of management when the United Mine Workers were controlling production in the bituminous industry in 1949 by means of three day work weeks; industry representatives testified that such produc- 
at the expense of the consumer. Higher prices mean more switching to oil and gas for heating. The most efficient way to compete with oil and gas is to drive out the high cost producers by unlimited competition and to enable the remaining operators and reorganized companies to receive the benefits of lower costs through mass production and full-time utilization of investment. Probably this would result in a certain concentration of ownership, but concentration would be great only if very large producers proved more efficient than small ones. ${ }^{139}$

A serious problem might be created by the unemployment of miners whose employers were forced by competition to close. Bootlegging would, as a result, also be encouraged, but this kind of unemployment, analogous to technological unemployment, should receive a positive social treatment by government other than subsidizing the mines. The money now spent by consumers in higher prices, supporting these extra miners, should be devoted to greater consumption in other areas, thus creating new jobs elsewhere and obtaining more goods. The fact that it is very difficult for a state to take this long range view only emphasizes the necessity for national rather than local control. ${ }^{\mathbf{1 4 0}}$

The pressure of price competition would be somewhat detrimental to conservation in encouraging the waste of hard-to-get coal, but anthracite coal conservation is unlike oil or even bituminous conservation. Under present property law it pays each oil well owner to pump as much as he can to obtain more than the adjoining well owners drawing from the same field. ${ }^{141}$ Hard coal, unlike bituminous, can be stored for some time. The threat to conservation in the anthracite industry arises from a pressure to close the mine after mining the coal easiest to extract, leaving the timbers to rot and the mine to cave in. This pressure is present today, although not so severe as during a period of real competition when high cost producers are being driven out. It would seem that the savings to society from lower prices are more important than possible expenditures in reopening mines, should a new rise in demand ever necessitate it. That rise may never occur.

tion control created inefficiency, that full production was necessary to support the high capital investment, to promote mechanization, and that greater costs were incurred because the efficiencies of mass production were prevented. It would appear that the effect of production control on costs would not differ because the coal was anthracite rather than bituminous. Hearings before Senate Committee on Banking and Currency on Economic Power of Unions, 81st Cong., 1st Sess. (1949). Idle but open anthracite mines incur costs from ventilation, pumping, safety inspections, and other maintenance operations which account for perhaps as much as one fifth of the retail anthracite price or $\$ 75,000,000$ per year. Glenn $O$. Kidd, speech to the New Jersey Coal Dealers Association, February 26, 1953. 1941).

139. See FTC, Relative Efficiency of Business (TNEC Monograph 13,

140. Compare the provisions under the Schuman Plan for reemployment with the aid of the High Authority of workers who lose their jobs through dislocations caused by the sudden creation of a free international market. TREATY ConstituTING tae European Coal and Steel Community, Convention Containing the Transitional Provisions $\$ 23$ (1951).

141. See Rostow, A National Policy for the OnL Industry 17, 43 (1948). 
Basically, the anthracite industry is not much different from any other in the effects of price competition on capital, labor, and quality of product. If free enterprise as protected by the Sherman Act is to remain our national economic policy, the Parker doctrine should be rejected for anthracite in order to reassert competition as the regulator of price and investment. Present deficits in some parts of the industry reflect the inept use of invested resources necessitated by production control. ${ }^{142}$ Regulation in excluding competition from some areas too often neglects to make controls coextensive with the areas excluded. ${ }^{143}$ If restriction of competition in production and prices is allowed, then public interest demands regulation of the other economic incidents of the industry.

If real competition in anthracite is not to be allowed, there may be justification for other industries to demand production "stabilization" as a solution for their economic problems. In view of the experience with cartels in Germany between the World Wars, where permission to form voluntary cartels gradually developed into power to compel membership, permission once granted threatens to become private economic government without any competition. ${ }^{144}$ There is little doubt that a return to real competition in the anthracite industry would be the alternative closest to the national policy expressed in the Sherman Act.

Private Monopoly: The Other Extreme.-Competition in anthracite, as in all industries, has some wasteful aspects. Recognizing this fact, a leading spokesman of the anthracite industry has suggested consolidation into one large private company with the cooperation of the federal and state governments. ${ }^{145}$ Not only could high cost operations, which function today under the protection of production control, be closed in favor of full time production from low cost mines, but competitive sales promotion could be cut $80 \%$, resulting in a $\$ 12,000,000$ annual saving to the industry. ${ }^{148}$ Assuming that such a saving would be used to benefit the consumer, a single-corporation plan might appear to be a good one; but it is highly unlikely that the consumer would gain any advantage from a private monopoly without some form of guarantee through public regulation.

Public Utility.-If resort were had to a single anthracite corporation, the consumer interest could be maintained by making such an organization a public utility. ${ }^{147}$ Utility controls are the usual form of comprehensive regulation, particularly where it is necessary to promote conservation,

142. E.g., Mines were worked on an average of four days per week in 1950. Anthractie Institute, Manual of Statistical Information Table 10 (1953).

143. Stocking and Watkins, Monopoly and Free Enterprise $377-8$ (1951).

144. Kronstein, Cartel Control-A Record of Failure, 55 YALE L.J. 297 (1946). For the methods of cartelization utilized in European economies, see Derrirtment of State, Foreign Legislation Concerning Monopoly and Cartels (1952).

145. Glenn $\mathrm{O}$. Kidd, speech to joint meetings of Greater Philadelphia Fuel Conference and Philadelphia Coal Club, March 11, 1953.

146. Iotd.

147. See note 132 supra. 
safety, and national defense (assuming this to be the case with anthracite). Public utility controls lessen the importance of the function of the investor to absorb losses. His right to profits correspondingly decreases. The consumer, of course, gains by regulation of price and investment.

The public utility, however, is usually characterized by its performance of a service in which competition is prohibitively wasteful by reason of duplication in investment. Anthracite does not seem to be analogous in this respect to normal utilities. Furthermore, utility regulation has ordinarily been imposed where the service involved is clearly necessary to the public welfare. That this is doubtful in the case of anthracite is witnessed by the growing replacement of anthracite by other fuels. ${ }^{148}$ An additional fact to be considered is that the delays encountered by utilities in changing rates and investment might be difficult for an industry which normally responds to market situations more rapidly and to a much greater extent than do other utilities.

The fact that anthracite is dissimilar in many respects to some concepts of public utilities, however, should not preclude possible adaptations to meet the industry's situation. Even without consolidation into a single company, anthracite price regulation could be carried out in a manner similar to existing milk price regulation. ${ }^{149}$

Public Ozonership.-Dince the above alternatives, with the exception of unrestricted competition, would lessen the risks of competition to the investor, his function may be so reduced in a declining industry, which needs less risk capital, as to warrant purchase by a public corporation. This could effect the economies of full utilization of investment and elimination of duplication while adjusting the interests of low prices, conservation, safety and national defense. National ownership in the United States is subject, however, to varied economic and political obstacles. Moreover, a single corporation, public or private, would eliminate any of the possible economies from the small scale operations of free competition. ${ }^{150}$ Besides the political and economic difficulties in public ownership, the legal limitations upon such a scheme have not as yet been adequately defined. ${ }^{151}$

The five alternatives have been considered in the light of the history of decline in the anthracite industry since 1917. There are some indications, however, that coal, generally, will be increasingly used as an industrial fuel in the future; the development of new uses for coal is also a factor. Estimates foresee a rise in production of about $60 \%$ from 1950 to $1975 .{ }^{152}$ It is quite possible that anthracite, as well as bituminous, may be

148. See Table II supra. But cf. note 152 infra.

149. See Agricultural Marketing Agreement Act of 1937, 50 Stat. 247 (1937), 7 U.S.C. $\$ 608 \mathrm{c}(1946)$. 1941).

150. See FTC, Relative Efficiency of Business (TNEC Monograph 13,

151. See Ashwander v. TVA, 297 U.S. 288 (1936); Atomic Energy Act, 60 StAT. 755, 42 U.S.C. $\$ \$ 1801-19$ (1946).

152. 1 Prestdent's Materials Policy Commission, Resources for Freedom 115 (1952). See also Woytinsky and Woytinsky, World Population and Pro- 
expected to share in the increased consumption. These considerations may compel future re-evaluation of the desirability of the five alternatives. In an expanding market there is no justification for production control. With increased consumption would come a need for risk capital, which can best be attracted under competitive conditions; in addition, the wastefulness of duplication in free enterprise would be minimized although not eliminated.

\section{CONCLUSION}

Since 1910 the operators have lost three anti-trust prosecutions. ${ }^{153}$ Whether the anti-trust policy ever succeeded in restoring competition for any length of time may well be questioned. Substantial doubt is cast on the ability of private enterprise to operate the anthracite industry competitively. As soon as real competition occurred, the industry succeeded in persuading a governor to promulgate a control plan which his legislature had in effect rejected eight months previously. Fifteen months later production control became legal when industry and union persuaded the state legislature to enact the Plan. The existence and application of the doctrine of Parker $v$. Brown does not merely represent a threat to the standard of living by increasing costs. It threatens democratic government by encouraging industry to seek abrogation of the Sherman Act by state legislatures without consideration of consumer interests. The ability of the anthracite industry to prevent unfavorable legislation, to obtain executive action when the legislature rejects action, and finally to obtain the enactment of its own program has been shown. Seldom is the translation of private economic power into political power so manifest.

DUCTroN (1953). "The use of fuels extracted in liquid and gaseous form from the earth's crust will probably . - approach its completion by the end of this century. The era of coal, which began 150 years earlier, is likely to continue longer...; Excerpt quoted in Time, Nov. 30, 1953, p. 95, col. 3.

153. Two suits have resulted in convictions. United States v. Reading Co., 226 U.S. 324 (1912) ; United States v. Reading Co., 253 U.S. 26 (1920); in the third the defendants pleaded nolo contendere. United States v. Glen Alden Coal Co., Criminal No. 113-391, S.D.N.Y. (pleas of nolo contendere entered May 2, 1944). 